\title{
O movimento argentino pelos direitos humanos: um estado da questão (1985-2019)
}

Marcos Tolentino ${ }^{1}$

Resumo: O objetivo do nosso artigo é traçar um estado da questão dos estudos sobre o movimento argentino pelos direitos humanos para compreender de que maneira se produziu uma narrativa histórica que vincula a luta em defesa dos direitos humanos e a resistência durante os anos da mais recente ditadura civil-militar na Argentina (19761983). Essa narrativa histórica surgiu ainda nos anos 1980, em análises que buscavam delimitar quais atores faziam parte do chamado movimento de direitos humanos. No final dos anos 1990, a incorporação da memória como tema de investigação iniciou um processo de questionamento sobre os imaginários, práticas e discursos que constituíram a luta pelos direitos humanos. Nos últimos anos, fruto sobretudo do acesso a acervos documentais e à utilização da metodologia da História Oral, notamos o reconhecimento de outras memórias, histórias e perspectivas que ampliaram o nosso entendimento sobre a configuração da luta dos direitos humanos na Argentina.

Palavras chave: Argentina; história recente; movimentos sociais; direitos humanos.

\section{The Argentine human rights movement: a bibliographical review (1985-2019)}

\begin{abstract}
The purpose of our paper is to outline a bibliographical review on the Argentine human rights movement and to understand the production of a historical narrative linking the struggle for human rights and the resistance during the years of the most recent civilmilitary dictatorship (1976-1983). In the 1980s, the first analyses that sought to delimit which actors were part of the so-called human rights movement produced this historical narrative. In the 1990s, the incorporation of memory as a research theme by academics emerged a process of questioning the imaginary, practices and discourses that constituted the "human rights field". In recent years, especially because of the access to human rights archives and the use of Oral History methodology, we have noticed the recognition of other memories, stories and perspectives that broadened our understanding on the configuration of the human rights mobilization in Argentina.
\end{abstract}

\footnotetext{
${ }^{1}$ Mestre em História pela Universidade Estadual de Campinas. Doutorando em História na Universidade Estadual de Campinas, onde desenvolve o projeto de pesquisa "Porque sabemos a verdade, temos memória, exigimos justiça. A trajetória da Asociación de Ex Detenidos-Desaparecidos na luta pelos direitos humanos na Argentina (1984-2014)", sob orientação do Prof. José Alves de Freias Neto, que contou com o financiamento do Conselho Nacional de Desenvolvimento Científico e Tecnológico (CNPq).

Endereço para correspondência: Rua Praia de Mar Grande, 2015, Vilas do Atlântico, Lauro de Freitas/Bahia, Cep: 42707-690. E-mail: marcosoat@hotmail.com.
} 
Keywords: Argentina; recent history; social movements; human rights.

\section{Artigo recebido em: 31/01/2020}

\section{Artigo aprovado para publicação em: 16/03/2020}

$\mathrm{Na}$ segunda metade do século XX, durante os processos de ditaduras civismilitares nos países do Cone Sul latino-americano, e nos respectivos processos de redemocratização, notamos o surgimento e/ou afirmação pública de diversas organizações que constituíram uma ativa resistência aos regimes ditatoriais e às consequências da violência política, e que articularam diversos setores da sociedade civil em torno da bandeira da defesa dos direitos humanos. Nesse quadro, o movimento argentino pelos direitos humanos é reconhecido como um dos mais importantes e exitosos, tanto pela relevância internacional adquirida por alguns dos organismos locais e algumas de suas figuras notáveis, como pelas respostas dadas pelo Estado argentino a algumas de suas demandas.

De acordo com Samantha Viz Quadrat (2008), a trajetória dos direitos humanos na América Latina contemporânea teria se iniciado na década de 1940, quando os governos de alguns países da região assinaram os primeiros documentos que prescreviam uma série de valores morais para a sua promoção. Esses acordos estiveram mediados por organizações intergovernamentais, como a Organização dos Estados Americanos (OEA) e a Organização das Nações Unidas (ONU), em um momento no qual, devido à experiência da Segunda Guerra Mundial, a promoção dos direitos humanos se tornou um importante ponto de pauta na agenda mundial. A partir dos anos 1960, com a emergência das ditaduras nos países do Cone Sul, em um quadro de uso extensivo da violência política e da tortura, a promoção e, sobretudo, a defesa dos direitos humanos não ficaram restritos aos espaços governamentais: nota-se a partir de então a proliferação de organismos nacionais ou internacionais atuando na região. Nos anos 1970, a relação entre esses organismos resultou na formação do que Kathryn Sikkink (2006) definiu como a "rede de direitos humanos latino-americana", na qual os grupos de direitos humanos da região se conectaram entre si e com uma grande quantidade de atores internacionais, como a 
Anistia Internacional (AI), a Cruz Vermelha e o Human Rights Watch (HRW), para protestar contra as violações cometidas pelas ditaduras e pressionar no cenário internacional por mudanças. O groso da sua atividade se deu em torno da informação e da denúncia, o que envolvia a reunião, a publicação e a disseminação de informações sobre os crimes de tortura, desaparecimento forçado de pessoas, prisões ilegais, perseguições e assassinatos políticos. Essa atuação em rede dotou os movimentos locais de um caráter transnacional, já que seu acionar não se restringiu às respectivas fronteiras nacionais. Essa experiência fez com que, segundo Samantha Viz Quadrat, se produzisse um senso comum que associa o período entre 1960 e 1980 como o momento fundador das violações aos direitos humanos, apesar delas terem uma longa existência na história latino-americana (QUADRAT, 2008, p. 384).

Em relação ao caso argentino, as violações aos direitos humanos e as respostas da sociedade civil a elas não se iniciaram como consequência do chamado terrorismo de Estado dos anos 1970 e 1980. A história política do país no século XX foi marcada por golpes de Estado e governos autoritários que implementaram uma sistemática perseguição a grupos políticos, inicialmente anarquistas e comunistas vinculados ao movimento operário, e militantes peronistas a partir de 1956. A configuração da luta pelos direitos humanos no país se deu, então, a partir da interação entre as modalidades da repressão e das modificações nas respostas sociais a elas e aos seus legados, trama na qual se inscreveu o surgimento de diversos organismos de direitos humanos e de um movimento social a partir das relações estabelecidas entre eles, com organismos internacionais e com o Estado. Entretanto, apesar de uma longa história que vai além da última ditadura, podemos perceber na Argentina a consolidação de uma narrativa histórica sobre a luta pelos direitos humanos que considera o 24 de março e o ano de 1976 como ícones de referência automática para uma experiência de violência radicalmente distinta e isolada historicamente. Um parêntesis histórico que se iniciou do nada, desconsiderando a reconfiguração progressiva da violência estatal e das violações aos direitos humanos ao longo do século XX, e sobretudo durante a década de 1970, e das 
respostas sociais a elas (FRANCO, 2015). Paralelamente, notamos uma ênfase posta nas trajetórias dos familiares das vítimas da última ditadura, principalmente familiares de desaparecidos, com um corte geracional - primeiro as mães e as avós, depois os filhos/filhas -, em detrimento de outras experiências, espaços e perfis de militantes.

A consolidação dessa narrativa histórica fez com que, segundo Ludmila da Silva Catela, na vida política e intelectual argentina, o entendimento da luta pelos direitos humanos esteja geralmente limitado a algo relativo à última ditadura e ao terrorismo de Estado. Logo, as palavras "direitos humanos" remetem automaticamente a um "passado que não passa": a última ditadura, os desaparecidos, a tortura, os centros clandestinos de detenção, as crianças apropriadas, os presos políticos, o exílio. Consequentemente, condiciona-se a leitura das violações aos direitos humanos no presente, em contraste ou continuidade com uma matriz de interpretação relativa ao passado recente de violência estatal e paraestatal e às formas de se fazer política e criar demandas de justiça inventadas e consagradas, principalmente pelos organismos de familiares de vítimas (DA SILVA CATELA, 2008).

Em relação à produção bibliográfica, Luciano Alonso apontou que o movimento argentino de direitos humanos já gerou muitas intepretações e investigações acadêmicas, jornalísticas e testemunhais, o que, à primeira vista, dificultaria o surgimento de novas questões e enfoques, pois as linhas de uma interpretação geral sobre a sua trajetória já estariam fixadas. Soma-se a isso a dificuldade de se produzir análises sem colocar em questão um movimento com o qual os investigadores e intelectuais tem normalmente algum tipo de sintonia. Surge então o questionamento sobre como problematizar as memórias de luta dos organismos de direitos humanos sem questionar a sua legitimidade como demandantes, empreendedores e promotores de ações sociais, culturais e estatais de recuperação e reparação do recente passado ditatorial (ALONSO, 2008, p. 88-90; ALONSO, 2010).

A consequência do que foi apontado por Ludmila da Silva Catela e por Luciano Alonso é um entendimento limitado da luta pelos dos direitos humanos na Argentina, 
como uma mobilização que se restringiu apenas aos "oito organismos históricos de direitos humanos", que protagonizaram a resistência contra a última ditadura - o Servicio de Paz y Justicia (Serpaj), o Movimiento Ecuménico por los Derechos Humanos (MEDH), a Asamblea Permanente por los Derechos Humanos (APDH), o Centro de Estudios Legales y Sociales (CELS), Asociación Madres de Plaza de Mayo, Madres de Plaza de Mayo Línea Fundadora, Familiares de Detenidos y Desaparecidos por Razones Políticas (Familiares) e Abuelas de Plaza de Mayo. A eles se somaram, a partir de 1996, Hijos por la Identidade y la Justica contra el Silencio y el Olvido (H.I.J.O.S.). Entretanto, de acordo com Virginia Vecchioli, mesmo entre os organismos tidos como parte do "movimento de direitos humanos", haveria uma distinção entre aqueles formados por familiares, que recebem maior reconhecimento e protagonismo público, e os outros que se tornaram conhecidos por seus militantes terem outros perfis sociais. Essa distinção resultaria em uma escassez de bibliografia sobre o segundo grupo, reveladora de alguns sentidos comuns que conduzem as formas de se abordar o movimento de direitos humanos na Argentina:

\begin{abstract}
La mayor visibilidad con que Madres, Abuelas y Familiares denunciaron el accionar represivo del Estado durante la última dictadura militar (1976-1983) ha tenido efectos críticos en la manera en que se seleccionan y delimitan el espacio y el tiempo en la literatura especializada: a) se da prioridad a aquellas asociaciones fundadas en la sangre y el parentesco como principios de reconocimiento público y, b) se periodiza la lucha en defensa de los derechos humanos en torno al golpe de Estado de 1976. Como resultado, quedan en las sombras a) las formas de activismo que se fundan en otros principios de reconocimiento como el derecho o la religión, por ejemplo, y, b) las formas de activismo en defensa de los derechos humanos previas a 1976 o posteriores al retorno a la vida democrática, aun cuando la existencia de asociaciones de defensa de los derechos humanos, como la LADH, se remonte a las primeras décadas del siglo XX o, cuando se registre hoy el surgimiento de nuevas asociaciones que se reconocen o son reconocidas públicamente por reivindicar la defensa de los derechos humanos, aun cuando no estén necesariamente vinculadas a las consecuencias del terrorismo de Estado (VECCHIOLI, 2012, p. 2-3).
\end{abstract}

Notamos paulatinamente, a partir dos anos 2000, a contribuição do campo de estudos sobre a memória para se repensar a história do movimento argentino pelos direitos humanos e se problematizar algumas dessas verdades e sensos comuns. Esses trabalhos 
partem das discussões sobre quem detém o capital simbólico dos direitos humanos, que no caso aqui discutido se definiu como a capacidade de demandar a sua proteção e de impor sentidos, demandas e práticas em torno do passado recente, com centralidade na experiência do terrorismo de Estado. Questionam, sobretudo, o reconhecimento de uma condição de vítima que dotou os familiares de desaparecidos e os organismos formados por eles de uma voz legítima autorizada para falar e demandar, quase que exclusivamente, sobre esse passado (JELIN, 2010; CRENZEL, 2015). Percebem-se, então, disputas para definir a própria noção de "direitos humanos", qual o seu conteúdo e alcance, pois: "Es una categoría que a la vez tiene un cariz universal (los derechos humanos son justamente derechos de todos los seres humanos) no puede ser pensada sin su anclaje particular. Es decir, en relación con el uso situado que los actores hacen de dicha categoría, lo que no tiene nada de universal" (CUETO RUA, 2018, p. 108).

Algumas inciativas institucionais também têm gerado uma renovação nos estudos sobre a luta pelos direitos humanos na Argentina por meio do acesso a fontes documentais e orais. Apesar de parte significativa dos organismos de direitos humanos terem atuado em condições de semiclandestinidade, que conspiraram contra a preservação de sua documentação, e desta tarefa não ter sido uma urgência com o fim da ditadura, um dos seus atuais empreendimentos de memória tem sido a formação de arquivos históricos que preservem o registro de suas lutas (JELIN, 2017). Em 2007, no marco do programa "Memorias do Mundo", a UNESCO incorporou o patrimônio documental de 29 arquivos referentes à luta pelos direitos humanos na Argentina como patrimônio da humanidade. Esse programa não estabeleceu regras referentes ao seu acesso, mas contribuiu para a preservação e divulgação dos documentos (GINZBERG, 2007). O acesso a esse material tem sido facilitado não só pelos organismos, mas também por instituições como o Memoria Abierta, o Centro de Documentación e Investigación de la cultura de Izquierdas (CeDinCi), e o Archivo Nacional de la Memoria (ANM). Além disso, por ter se tratado de uma mobilização transnacional, parte do acionar do movimento argentino pelos direitos humanos pode ser estudada por meio dos acervos de organismos que atuaram em 
outros países, como, por exemplo, o Brasil, onde funcionou o Comitê de Defesa dos Direitos Humanos no Cone Sul (Clamor), cujo arquivo pode ser consulado no Centro de Documentação e Informação Científica (Cedic), na Pontifícia Universidade Católica de São Paulo (PUC-SP). Soma-se a esses a produção de arquivos orais audiovisuais que contam com testemunhos de diversos perfis de indivíduos que se envolveram na luta pelos direitos humanos na Argentina, refletindo uma pluralidade de experiências, enfoques e pertencimentos institucionais, como, por exemplo, o Arquivo Oral do Memoria Abierta e o Programa de Derechos Humanos da Biblioteca Nacional Mariano Moreno. Fora da cidade de Buenos Aires, outras instituições como a Comisión Provincial por la Memoria (CPM), em La Plata; o Museo de la Memoria, em Rosario; e o Archivo Provincial de la Memoria, em Córdoba, também conjugam ações de preservação e abertura para a consulta pública de arquivos relacionados às lutas locais pelos direitos humanos com a produção de arquivos orais.

A partir do que foi exposto, o objetivo do nosso artigo é traçar um estado da questão dos estudos sobre o a luta pelos direitos humanos na Argentina, para compreender de que maneira se produziu uma narrativa histórica que a vincula à resistência durante os anos da mais recente ditadura civil-militar argentina e às demandas em torno dos seus legados, cuja permanência a nosso ver silencia a sua heterogeneidade, reafirma níveis de legitimidade e de protagonismo e limita o nosso entendimentos sobre a configuração do campo dos direitos humanos no país. Essa narrativa histórica surgiu nas primeiras análises, ainda nos anos 1980, que buscavam delimitar quais atores faziam parte do chamado movimento de direitos humanos, limitando-os a uma lista de oito. A partir dos anos 1990, a incorporação da memória como catalizadora de mobilizações pelos organismos e, paralelamente, como tema de investigação pela academia iniciou um processo de questionamento sobre imaginários, práticas e discursos que constituíam o campo dos direitos humanos e produziam distintos sentidos e memórias em conflito sobre o terrorismo de Estado e os seus legados. Ao final dos anos 2000, ao se garantir o acesso a acervos documentais e se utilizar da metodologia da História Oral, e com a consolidação 
do campo da História Recente, notamos o reconhecimento de outras memórias, histórias e perspectivas que têm ampliado o nosso entendimento sobre a configuração do movimento argentino pelos direitos humanos e sobre as disputas de legitimidades que ocorrem em seu interior.

\section{O movimento de direitos humanos e os "novos movimentos sociais"}

Em um artigo publicado em 2004, Elizabeth Jelin analisou como os direitos humanos se tornaram um campo de análise para as Ciências Sociais na América Latina. De acordo com a autora, a incorporação dos direitos humanos à luta anti-ditatorial teria resultado numa "revolução paradigmática", pois, até então, as lutas sociais e políticas na região eram interpretadas em termos de lutas de classe ou das revoluções nacionais. Além disso, a incorporação das demandas dos direitos humanos na agenda social e política das transições democráticas, nos anos 1980, teria ocorrido em um momento em que as Ciências Sociais estavam voltando a sua reflexão para a noção de democracia, entendida em oposição ao autoritarismo e às ditaduras. Nesse quadro, os direitos humanos foram compreendidos como direitos inalienáveis, sendo o Estado responsável de garantir a sua vigência e o seu cumprimento, valores essenciais para o fortalecimento dos regimes democráticos. Além de pensar na relação entre democracia e direitos humanos, as Ciências Sociais se voltaram às formas de expressão da cidadania, principalmente o surgimento dos chamados "novos movimentos sociais" e a novidade das suas práticas entendidas, não só nas formas de se fazer política, mas também pelas novas formas de sociabilidade, representatividade e de padrões da organização social que eles geravam (JELIN, 2004).

Sebastián Pereyra apontou que o fim das ditaduras resultou em uma revitalização da atividade política e uma diversidade de formas de participação política por vias da mobilização, não só de atores políticos tidos como tradicionais e seus canais formais como os sindicatos e partidos -, mas também de novos atores - como as organizações de 
bairro, os jovens e a sua relação com o rock nacional, as mulheres e os organismos de direitos humanos -, o que então se denominou como "novos movimentos sociais" (PEREYRA, 2008, p. 21-32). Nesse quadro, de acordo com Luciano Alonso (2008), alguns organismos de direitos humanos suscitaram a atenção intelectual, tornando-se ícones da resistência ao poder militar e da luta pela vida frente à violência estatal, em estudos que se voltaram ao seu impacto na ditadura e na chamada transição democrática, para a formação de um "novo imaginário republicano". Segundo Mauricio Chama e Hernán Sorgentini (2011), as primeiras análises sobre o movimento argentino de direitos humanos produzidas nos anos 1980 tomaram então como referência teórica o modelo dos "novos movimentos sociais", enfatizando a "novidade" de um movimento, assim como a expectativa positiva que despertava sua potencial capacidade de abrir novas e mais intensas formas de participação política, e sobretudo social.

Nesse primeiro momento de produção bibliográfica, a preocupação central era definir o que seria a luta pelos direitos humanos a partir de um mapeamento dos organismos que constituam o movimento. Nota-se então a produção de uma narrativa histórica, segundo a qual teriam sido oito os organismos de direitos humanos na Argentina: a LADH, Mães e Avós de Praça de Maio, Familiares, o CELS, o MEDH, a APDH e o SERPAJ. Tal narrativa pode ser analisada no livro "Las organizaciones de derechos humanos", publicado em 1985 por Raúl Veiga. No prólogo do livro, Rodolfo Colángelo afirma que, com exceção à LADH, o restante dos organismos surgiu durante os anos da ditadura iniciada em 1976: "Primero, como un tímido intento de denunciar e esclarecer los casos de cientos de desaparecidos y detenidos políticos, y posteriormente como parte integrante de la resistencia a la dictadura" (VEIGA, 1985, p. 10). Além disso, ele aponta que os organismos podem ser divididos de acordo com os perfis de seus militantes - entre afetados diretos ou não pela repressão; e por sua metodologia de trabalho e objetivos, a princípio definidos “confusamente”. É dado, então, um destaque às Mães da Praça de Maio, como "aríete e motor na defesa dos direitos humanos na Argentina", e por terem "iniciado" a resistência pública à ditadura: 


\begin{abstract}
Como una fantasmal aparición, esas mujeres que lucían pañuelos blancos en sus cabezas, algunos bordados con los nombres de los hijos desaparecidos, comenzaron a movilizarse en torno a la Pirámide de Mayo mientras el régimen se mantenía seguro e inconmovible dentro de la Casa Rosada. Sin dudas, el general Jorge Rafael Videla, primer presidente del 'Proceso', no imaginaba que esas mujeres se convertirían con el tiempo en una terrible y obsesiva pesadilla para el régimen militar (VEIGA, 1985, p. 11).
\end{abstract}

Na parte dedicada às Mães da Praça de Maio, Raúl Veiga, volta a afirmar o seu protagonismo no interior do movimento pelos direitos humanos. Segundo o autor, tanto a opinião pública como os políticos reconheciam que elas tinham sido as "primeiras" e "mais consequentes combatentes contra a ditadura". A novidade que elas representam é destacada pelo fato de que, antes de se mobilizarem, as madres seriam mulheres anônimas de distintas classes sociais que haviam dedicado suas vidas a "questões mundanas totalmente distantes dos acontecimentos políticos"; "ocupando-se de suas casas, seus maridos e seus filhos". Motivadas pelas esperanças de encontrar seus filhos desaparecidos com vida, elas teriam gerado um "movimento espontâneo", "inesperado" pelos militares, que "não poderiam imaginar" que elas seriam capazes de "transformar o choro em organização e resistência contra a ditadura" (VEIGA, 1985, p. 26-30).

A narrativa histórica dos oito organismos de direitos humanos foi reforçada também por Héctor Ricardo Leis (1989), nos dois volumes publicados por ele sobre o movimento de direitos humanos. De acordo com o autor, o que então se entendia por movimento de direitos humanos teria sido formado pelos oito organismos durante a ditadura, pois, apesar de alguns terem surgido antes de 1976, foi na luta por respostas às graves violações aos direitos humanos que eles se encontraram e alcançaram relevância. Além disso, a sua heterogeneidade inicial "parecia" ser o "resultado de uma divisão natural do trabalho contra a ditadura", e, não, das diferenças internas do movimento. Para o autor, o movimento de direitos humanos constituiria um "movimento social novo", que tinha como "evidência empírica" dessa novidade o fato de que as organizações que "acabavam hegemonizando a cena política em torno aos direitos humanos" eram as que 
estavam distantes de propostas de corte "mais político ou ideológico". Nota-se então uma separação clara entre os organismos de direitos humanos e os tradicionais partidos políticos que, segundo o autor, "comprometeram sempre um apoio reticente aos direitos humanos". O entendimento do movimento de direitos humanos como alheio à política tradicional surgiu também a partir de uma análise de Inés González Bombal (1987), na qual ela caracterizou a luta pelos direitos humanos como "um acontecimento" gerado por um discurso que se colocava "fora da política" para criar "uma outra política".

A leitura dessas análises publicadas nos anos 1980 demonstra que elas entendiam a luta pelos direitos humanos como algo que traduzia adequadamente as oposições entre civis e militares, ditadura e democracia. Nesse sentido, Héctor Ricardo Leis (1989) apontou a demanda dos direitos humanos como "condição essencial da democracia", uma "ponta do iceberg" de uma concepção global sobre a construção da ordem democrática que "particularmente" no Cone Sul latino-americano chegou "como efeito inesperado". A oposição à última ditadura civil-militar argentina parecia construir, então, um sentido de unidade entre os oito organismos, apesar da diversidade dos seus integrantes, suas trajetórias, suas propostas ideológicas e seus graus de compromisso (CHAMA, SORGENTINI, 2011).

De acordo com Santiago Cueto Rúa (2017), durante os anos 1980, a ideia de "movimento" foi central como categoria analítica capaz de dar conta da novidade que supunha o coletivo dos organismos. Nesse sentido, Luciano Alonso (2014) aponta que apelar para a noção de "movimento de direitos humanos" e para a "lista dos oito organismos", ao mesmo tempo em que se afirmava a existência de um novo ator político, diferenciava se os grupos que faziam parte delas por outras experiências prévias, principalmente de organismos de direitos humanos surgidos antes da última ditadura e que tinham vínculos partidários claros. Podemos entender, assim, o destaque recebido pelas Mães da Praça de Maio e do seu discurso que associava a sua mobilização à maternidade e a uma suposta espontaneidade, e não a uma escolha de formas de se fazer política e estratégias de mobilização politicamente adotadas pelo grupo de mulheres. 
A história do movimento argentino de direitos humanos que então se consolidou teria começado como consequência do golpe de Estado de 1976, principalmente a busca pelos desaparecidos, apesar de metade dos oitos organismos terem surgido anteriormente, principalmente entre o final do governo de Isabel Perón e a última ditadura: a LADH (1937), o SERPAJ (1974), a APDH (dezembro de 1975) e o MEDH (fevereiro de 1976). Por um lado, estes promoveram o acolhimento aos familiares de vítimas e o apoio aos presos políticos e as primeiras formas de denunciar as violações aos direitos humanos de forma orgânica e sistemática, recopilando dados, iniciando as investigações, enquadrando juridicamente as desaparições e prisões, estabelecendo os primeiros contatos para que se conhecesse mundialmente o que acontecia na Argentina, trabalho ao qual se somariam posteriormente Familiares e o CELS. Por outro lado, foram as Mães da Praça de Maio que teriam iniciado publicamente a resistência à ditadura por meio das suas rondas das quintas-feiras, iniciadas em 30 de abril de 1977. Algumas delas teriam se separado do grupo inicial para fundar, em outubro de 1977, as Avós da Praça de Maio, que se dedicaram não só a buscar os filhos e filhas desaparecidos, mas também netos e netas sequestrados junto aos pais, ou aqueles que poderiam ter nascido durante o sequestro de suas mães (VEIGA, 1985, p. 58).

Em 1980, o movimento de direitos humanos teria conquistado reconhecimento internacional quando as Mães da Praça de Maio e Adolfo Pérez Esquivel, líder do SERPAJ, foram indicados ao Prêmio Nobel da Paz, o qual foi entregue a Pérez Esquivel. Consequentemente, no ano seguinte, os organismos teriam começado a hegemonizar ideologicamente a oposição à ditadura, instalando-se como um divisor de águas na história da cultura política argentina contemporânea ao reivindicar o direito à vida como valor principal da ordem política. A sua luta se viu eclipsada momentaneamente durante a Guerra das Malvinas (1982), porém, ao final do conflito, eles teriam conseguido instalar publicamente na Argentina a questão dos desaparecidos. Com o retorno à democracia, o movimento e sua unidade teriam sofrido fissuras devido às diferentes posições dos organismos em relação ao governo de Raul Alfonsín (1983-1989). Uma das questões 
centrais entre os organismos e que refletiu nessas primeiras análises sobre o movimento de direitos humanos foi a importância da aplicação da justiça para julgar os crimes cometidos pela ditadura. Ou seja, se ela gerava tensões no caminho para a consolidação democrática, ou se era uma questão central para tal consolidação (CHAMA, SORGENTINI, 2011).

\section{A primazia dos estudos sobre a memória}

Se na década de 1980, os primeiros estudos sobre o movimento argentino pelos direitos humanos o interpretaram a partir da noção de "novos movimentos sociais", a partir do final da década de 1990 e início dos anos 2000, os chamados estudos sobre a memória passaram a gerar as principais interpretações sobre o tema. De acordo com Elizabeth Jelin (2004), na década de 1990, as lutas pela memória e pelo sentido do passado se tornaram um campo de ação social na América Latina e, consequentemente, um novo campo de investigações sociais que buscavam entender as práticas e estratégias de mobilização que então se produziam. No caso argentino, ela aponta para o aparecimento do "mandato de memória" como uma das demandas do movimento de direitos humanos: "Recordar para no repetir fue surgiendo como mensaje y como imperativo moral" (JELIN, 2004, p. 104). Essa interpretação é compartilhada por Santiago Cueto Rúa (2017), que pontua que nos anos 1990, à medida que os governos argentinos retrocediam no cumprimento das demandas de julgar os responsáveis pelas violações aos direitos humanos, os organismos começaram a apelar à memória como um reclamo que se complementava com o de "verdade e justiça", surgidos durante a ditadura.

Tais análises dialogam com Ana Guglielmucci, que afirma que até meados da década de 1990, a criação de projetos voltados a recordar os desaparecidos e transmitir a memória sobre os crimes cometidos pelo terrorismo de Estado não era uma tarefa prioritária no interior do movimento de direitos humanos, nem um objetivo consensual entre todos os seus referentes. Para alguns organismos, a única forma de evocar 
publicamente os desaparecidos ainda consistia na multiplicação da mobilização política com o objetivo de atualizar as demandas ligadas às consignas de verdade e de justiça. De acordo com a autora, no final da década de 1980 e ao longo dos anos 1990, alguns projetos de criação de espaços que documentassem a vida dos desaparecidos e evocassem as suas memórias foram rechaçados por muitos organismos que concebiam tais propostas como "um placebo", "um mecanismo de individualização das vítimas" e que poderia desviar a histórica luta por alcançar a verdade sobre o destino dos desaparecidos e garantir o castigo a todos os culpados. Entretanto, em meio a tais debates, ocorreu uma "redefinição" do perfil do movimento de direitos humanos que paulatinamente passou a reconhecer a importância da memória como uma "ferramenta de luta contra a impunidade": "Paulatinamente, fue cobrando impulso la percepción de que lo pasado no sólo debía ser conocido y juzagado, sino también incorporado en la memoria de los argentinos a través de su recuerdo permanente" (GUGLIELMUCCI, 2013, p. 42).

Além dessa redefinição no perfil do movimento de direitos humanos, Mauricio Chama e Hernán Sorgentini (2011) apontam que alguns episódios ocorridos a partir da segunda metade da década de 1990 tiveram um peso nesse processo de primazia da memória: as declarações públicas de oficiais das Forças Armadas, como, por exemplo, as entrevistas de Adolfo Schilingo sobre os chamados "vôos da morte", e o surgimento de um novo organismo de direitos humanos, formado pelas filhas e filhos das vítimas da última ditadura (H.I.J.O.S.). Além disso, a ampliação da mobilização social em torno do vigésimo aniversário do golpe em 1995 e os debates em torno da "pacificação nacional" em 1996, fruto da resistência dos organismos às tentativas do governo de Carlos Menem de destruir o complexo de prédios nos quais funcionou durante a última ditadura o centro clandestino de detenção da Escuela de Mecánica de la Armada (ESMA), em 1998.

Paralelamente, a memória começou a ter centralidade na bibliografia que abordava esses atores, sob a influência, principalmente, dos debates sobre as consequências sociais e culturais das experiências de extermínio no século XX nos países europeus. Logo, autores e questões como, por exemplo, Maurice Halbwachs e os marcos 
sociais da memória; Michael Pollack e as relações entre memória e identidade e os debates sobre testemunho, esquecimento e silêncio; Dominick Lacapra e as relações entre memória e trauma e as suas possibilidades de representação; Tzvetan Todorov e as diferenças entre a memória exemplar e a literal. Todos contribuíram para a formação de um debate na Argentina sobre o que era a memória, principalmente qual a natureza das memórias do terrorismo de Estado e da última ditadura, quais agentes as impulsionavam, como se constituíam e qual o papel dos organismos de direitos humanos nesses processos.

Um dos primeiros textos a discutir questões que posteriormente seriam centrais para o chamado campo de estudos da memória foi o artigo de Elizabeth Jelin (1995), publicado na compilação Juicio, Castigos y Memorias. Algumas diferenças podem ser percebidas na sua análise em relação aos textos já citados. Em primeiro lugar, ela traça um panorama de como se constituiu o movimento argentino pelos direitos humanos e as suas demandas por memória, verdade e justiça, compreendendo-as como algo que não foi automático, mas sim fruto de diferentes expectativas, modos de ação e objetivos entre os organismos e dos conflitos entre eles e com o Estado. Devemos ressaltar que apesar de partir do modelo analítico do "movimento" para se referir aos organismos que se mobilizaram em torno dos direitos humanos na Argentina, Elizabeth Jelin não parte de uma suposta unidade entre eles, mas da heterogeneidade interna e da diversidade de estratégias, táticas, modalidades de ação e estilos organizativos dos seus componentes, importantes para se compreender os debates e rupturas com o final da ditadura. Ela afirma que até meados dos anos 1980, o eixo da sua ação esteve dado pela urgência do esclarecimento e a difusão da natureza das violações massivas e sistemáticas durante a última ditadura - a demanda de verdade e o reclame pelo castigo aos culpados - a demanda de justiça. Entretanto, a dificuldade de dimensionar o dano causado pelos desaparecimentos e os obstáculos para se atribuir responsabilidades geraram conflitos entre os organismos sobre qual verdade era produzida publicamente. Os conflitos em torno de se conseguir um julgamento efetivo dos militares responsáveis pelas violações aos direitos humanos se acirraram durante o governo de Raúl Alfosin (1984-1989). Apesar 
da política de direitos humanos então implementada ter se baseado no compromisso de investigar o passado, por meio da Comisión Nacional sobre la Desaparición de Personas (1984) e da realização do julgamento contra os militares responsáveis, ela também partia de um compromisso de limitar o alcance da responsabilização judicial de modo a manter uma relação harmônica com as Forças Armadas. Isso gerou uma divisão entre os organismos que se distanciaram das posições adotadas pelo governo e aqueles que privilegiaram a aproximação com a nova institucionalidade e aceitaram as regras do novo jogo político.

A segunda novidade desse texto é o argumento de que com o governo de Alfonsín, teria se iniciado um "período de declínio" dos organismos de direitos humanos em ditar as formas de tratamento do passado ditatorial, que se explicaria no fato de não conseguirem mais cristalizar um "inimigo" e um objetivo em comum, o que fez com que perdessem força de mobilização ao ponto de não conseguirem evitar a sanção das leis de Obediência Devia (1987), de Ponto Final (1988) e dos Indulto (1989 e 1990). Foi a partir dessa "derrota" institucional que a reivindicação da memória coletiva como forma de prevenir a repetição do terror experimentado na ditadura teria se tornado a bandeira central dos organismos de direitos humanos. Frente à "deterioração da justiça”, a memória se tornava "por excelência" o espaço no qual a sociedade podia elaborar social e culturalmente as contas com o passado e o campo de intervenção dos organismos. Entretanto, ela destaca o fato de que o não reconhecimento estatal de que o terrorismo de Estado havia sido uma experiência traumática poderia conferir às suas vítimas diretas uma autoridade simbólica, que por sua vez impossibilitaria o surgimento de novas vozes e significados dentro da luta pelos direitos humanos (JELIN, 1995).

Logo, o que Elizabeth Jelin aponta nesse texto, e que seria posteriormente analisado pelos estudos da memória, é a noção de que a luta pelos direitos humanos é marcada por conflitos, o que faria do movimento de direitos humanos uma frente heterogênea. Ademais, tais conflitos poderiam a ser interpretados a partir das diferentes versões e sentidos sobre o passado produzidos pelos atores sociais e organizações que 
participam dele. Algumas dessas ideias foram retomadas no livro Trabajos de la memoria (2002), no qual Elizabeth Jelin apresenta algumas ferramentas iniciais para analisar as "distintas memórias" produzidas nos países do Cone Sul e no Peru com o final das respectivas ditaduras. Para a autora, os processos de "abertura política" habilitaram cenários de "lutas pelo sentido do passado", entre os relatos oficiais produzidos pelos regimes ditatoriais e o surgimento de novas versões do passado e de outras que até então estavam contidas ou censuradas. Logo, não se tratava de uma disputa entre "memória" e "esquecimento", mas entre "distintas memórias". Atores sociais diversos, definidos por ela como "empreendedores da memória", com diferentes vínculos com a experiência passada, lutavam por afirmar a legitimidade da "sua" versão do passado e da "sua" verdade, em um cenário que dificultava a produção de consensos. No caso argentino, ela aponta o movimento de direitos humanos como um dos "empreendedores da memória privilegiado", com "presença permanente e sistemática", buscando o esclarecimento completo do ocorrido, com o correspondente castigo dos culpados pelas violações de direitos humanos, paralelamente impulsionando iniciativas e empreendimentos públicos para se registrar, preservar e comemorar o passado ditatorial.

O livro Trabajos de la memoria trazia em seu conteúdo os resultados de um programa de investigações e de formação de jovens investigadores do Cone Sul e do Peru sobre memória coletiva e repressão. Essas investigações foram publicadas em onze volumes, entre 2002 e 2005, nos quais podemos encontrar alguns artigos que, a partir dos pressupostos propostos por Elizabeth Jelin para analisar os "conflitos de memórias", tomaram diferentes iniciativas do movimento argentino pelos direitos humanos como objeto de análise: o artigo de Federico Lorenz (2002) sobre as comemorações do 24 de março; o de Patricia Valdéz (2003) sobre o projeto do Parque de la Memoria, em Buenos Aires (2003); o de Ludmila da Silva Catela (2004) sobre a marcha del Apagón, realizada em Jujuy, norte da Argentina; o de Laura Cecilia Mombello (2004) sobre as marchas pelos direitos humanos que tornaram Neuquén, no sul argentino, a "capital dos direitos 
humanos", e o de Pablo Daniel Bonaldi (2006) sobre as memórias produzidas pelas práticas de H.I.J.O.S.

Outro trabalho importante na conformação do campo de estudos da memória na Argentina foi o de Ludmila da Silva Catela (2001). A partir da análise de entrevistas realizadas com familiares de desaparecidos de diferentes gerações da cidade de La Plata, ela apontou como o desaparecimento foi vivenciado como uma "situação-limite" por eles, resultando em uma reconfiguração de suas identidades e de suas relações sociais. Apesar de não enunciar a quais organismos cada familiar se vinculou, podemos perceber por meio da sua análise que, em muitos casos, tais reconfigurações foram vividas no interior do campo dos direitos humanos. Ao circularem pelos mesmos espaços na sua busca por informações, tais homens e mulheres se reconheceram como iguais, criaram novas formas de ação e reformularam velhas práticas, tornando a sua busca individual em uma ação coletiva de denúncia e de interpelação ao Estado e à Justiça. Paralelamente, procuraram alternativas "mais criativas" e de impacto público como, por exemplo, a ocupação da praça como espaço de publicidade e visibilidade, os habeas corpus coletivos e as matérias pagas nos jornais. O resultado desse processo foi a produção de uma nova identidade: a de "familiar de desparecido". Essa identidade se configurou ainda a partir das práticas por meio das quais eles se posicionavam em torno da figura do desaparecido, e enunciavam um drama privado na esfera pública. A própria categoria de "desaparecido", como ela é entendida social e culturalmente na Argentina, seria fruto da sua ação e do seu entendimento das diferenças dessa modalidade repressiva para o assassinato político, principalmente o caráter inconcluso do desaparecimento. Consequentemente, a ação dos familiares produziu verdades em torno da prática repressiva dos desaparecimentos, como um crime cometido pelas Forças Armadas e pelo Estado contra toda a sociedade argentina, assim como dos desaparecidos, que tiveram as suas vinculações políticas silenciadas, enquanto foram exaltados seus "valores positivos e solidários". Além disso, estabeleceram rituais e comemorações que deixaram marcas na paisagem cultural urbana, 
criaram esquemas para a leitura do passado, ao mesmo tempo em que produziram discursos sobre a identidade dos familiares e dos desaparecidos.

Ambas as análises trazem em si a questão da memória como central para se analisar a luta pelos direitos humanos. Podemos observar que se o desenvolvimento desse campo de estudos se deu como consequência de a memória ter se tornado, desde meados da década de 1990, um campo de ação social para o movimento argentino pelos direitos humanos, alguns textos passaram a naturalizar a noção de que "memória, verdade e justiça" sempre haviam sido as demandas que mobilizaram essa ação. Nesse sentido, por exemplo, Hugo Vezzetti apontou que a oposição pública, "moral antes que política", dos organismos de direitos humanos, e das Mães da Praça de Maio em particular, se desenvolveu por meio da "estreita relação" entre três componentes de ação: (i) o reclamo pela verdade, sobretudo o destino da vítimas e a informação sobre os crimes cometidos pela ditadura; (ii) a demanda de justiça, que reclamava que, diferentemente das ditaduras anteriores, os delitos cometidos pelo Estado não ficariam impunes, (iii) e o imperativo da memória, ou seja, a luta contra formas "formas históricas ou institucionais" de esquecimento ou de falsificação do ocorrido (VEZZETTI, 2002, p. 21-22).

Em relação às análises sobre o movimento argentino pelos direitos humanos, podemos destacar quatro discussões que se tornaram centrais no campo de estudos sobre a memória. A primeiro deles é a historicidade das memórias, em textos que colocaram os discursos e práticas dos organismos de direitos humanos em perspectiva histórica, em uma tentativa de compreender como o tema das violações aos direitos humanos cometidos durante a última ditadura se manteve na cena pública como um dos paradigmas para a produção de sentidos sobre o passado ditatorial. Vale ressaltar que não se tratam de textos que analisam diretamente o movimento argentino dos direitos humanos, mas que o colocam como participante de uma dinâmica social, cultural e política de produção de sentidos sobre o passado.

Tais análises coincidem em apontar algumas etapas para se pensar a participação dos organismos de direitos humanos na história das representações sobre a última 
ditadura: (1) o período da ditadura (1976-1983), durante o qual o seu discurso teria sido o primeiro a questionar a versão oficial da "guerra contra a subversão", produzindo uma narrativa centrada no valor dos direitos humanos e da gravidade das violações cometidas pelos militares; (2) a "transição democrática" (1983-1986), na qual a luta pelos direitos humanos e a sua narrativa teriam sido centrais ao ponto de gerar desdobramentos no discurso e nas práticas do Estado, sem encerrar as divergências entre os organismos; (3) o período da "impunidade" (1987-1995), consequência da promulgação das "leis de impunidade" iniciada por Alfonsín, e da "política de reconciliação nacional” iniciada por Menem, no qual as reivindicações e o poder de convocatória dos organismos teriam atravessado uma debilitação na esfera pública, dividindo-os entre os que estavam abertos ou não para um diálogo com o Estado; (4) o chamado “boom da memória” (1995-2003), fruto do retorno da questão da memória da ditadura como central no espaço público, do incremento de poder de convocatória dos organismos e da multiplicação de suas práticas de rememoração; (5) a "institucionalização da memória", durante os governos de Néstor e Cristina Kirchner (2003-2015), quando o Estado teria assumido a demanda de memória defendida por alguns setores do movimento de direitos humanos, multiplicando as inciativas oficiais (CERRUTI, 2001; VALDEZ, 2001; LVOVICH, BISQUERT, 2008; CRENZEL, 2008, 2015).

A segunda discussão é sobre a relação do movimento de direitos humanos com as chamadas "políticas de memória" (RABOTNIKOF, 2008). Como vimos na discussão anterior, o Estado passou a se tornar um interlocutor central para se analisar de que maneira as práticas e discursos dos organismos foram se configurando em tensão com as formas de gerir o passado ditatorial implementadas pelos sucessivos governos. Ao analisar o histórico de "políticas de memória" na Argentina, os textos coincidem em apontar o período iniciado com a eleição de Néstor Kirchner como de "mudança" da relação entre o Estado e o movimento de direitos humanos, que resultou em uma “estatização da memória”. Esse processo seria consequência de uma gestão que passou a se identificar publicamente com algumas das demandas históricas dos organismos e a 
implementar uma gama de iniciativas simbólicas e políticas públicas ligadas à memória da última ditadura, como, por exemplo, a "recuperação", marcação e conversão dos espaços nos quais funcionaram centro clandestinos de detenção em "espaços de memórias"; a retirada dos retratos de militares ligados à repressão do Colégio Militar; o estabelecimento do 24 de março como feriado nacional; o pedido de perdão público e formal do Estado pelas violações aos direitos humanos; a revogação das "leis de impunidade" e a consequente retomada dos julgamentos dos crimes cometidos durante a última ditadura; a aproximação e o diálogo com alguns referentes do movimento de direitos humanos, como Hebe Bonafini e Estela de Carloto, dirigentes da Asociación Madres de Plaza de Mayo e de Abuelas, respectivamente, e a criação políticas de educação sobre memória e direitos humanos (JELIN, 2005; DA SILVA CATELA, 2010; BAUER, 2012; BALE, 2018).

Por outro lado, algumas análises destacam o fato de que esse maior diálogo entre o Estado e o movimento de direitos humanos não resultou no fim dos conflitos no seu interior. Nesse sentido, a bibliografia sobre "espaços de memória" abordaram de que maneira as práticas e discursos dos organismos de direitos humanos se configuraram a partir da formação desses espaços, como eles se posicionaram no campo de lutas para definir quais são os lugares que devem ser "recuperados", quem deve fazer parte desses espaços e quais relatos devem ser incorporados. Além disso, discutem a sobreposição de identidades e de formas de atuação por parte de militantes de direitos humanos que se tornaram funcionários do Estado em alguns dos "espaços de memória" que foram criados a partir dos anos 2000 (DA SILVA CATELA, 2010, 2014; CÚETO RUA, 2018b; FELD, 2017; GUGLIELMUCCI, 2013; MESSINA, 2010, 2016, 2019; LARRALDE ARMAS, 2019).

A terceira discussão é sobre a relação da memória com os processos de produção de identidades sociais. Esse processo foi principalmente analisado nos organismos formado por familiares de vítimas que tornaram o parentesco um dos princípios centrais de organização do universo da militância pelos direitos humanos e da sua identificação nos espaços públicos. Para Virginia Vecchioli (2005), a existência de familiares que não denunciaram publicamente a desaparição, que não se vincularam ao movimento de 
direitos humanos ou que militaram em outros organismos que não reivindicam os laços de sangue com as vítimas são o demonstrativo de que a condição mãe, avó, filho ou filha de uma vítima foi uma "propriedade socialmente construída e objetivada” por um grupo de militantes que se identificaram no espaço público e que tiveram uma prática ativa de militância na causa dos direitos humanos, reivindicando esse parentesco. Além disso, em seus discursos, os organismos de familiares naturalizam essa relação entre parentesco e militância, apontando que a sua força, coragem e resistência seriam fruto das relações de sangue entre as vítimas e suas famílias, e não o resultado de uma escolha de forma de atuação política. Consequentemente, a militância pelos direitos humanos é entendida como um "compromisso moral e intransferível”, distanciando-a das práticas políticas tradicionais e produzindo uma "identidade política neutra", pautada na condição de familiar sem vínculos políticos prévios. De acordo com Liliana Sanjurjo (2018), entre os familiares a identidade política é tida como uma "qualidade" associada à família e aos lanços de sangue: o compromisso político se funda no instinto, na natureza, no sangue, de modo que o "dever de memória" se expressa como decorrência natural das relações de parentesco. Além disso, tais relações funcionam como uma metáfora para a constituição de uma "comunidade moral": a "grande família" dos direitos humanos, que se reconhece entre si e que se perpetua por gerações, como um "legado político". A força das narrativas do movimento de familiares nos processos de definição da memória pública sobre a ditadura, aponta Liliana Sanjurjo, adquirem, em grande medida, o estatuto de "verdade" quando associadas aos campos jurídico e científico. Dessa forma, o vínculo sanguíneo, que atribui sentidos à sua experiência e à sua identidade, tornou-se a prova da "verdade" sobre a identidade dos bebês "apropriados" e dos desaparecidos enterrados em fossas comuns como indigentes.

A quarta discussão refere-se aos diferentes níveis de legitimidade no interior do movimento de direitos humanos. Essa legitimidade se constrói a partir de alguns fatores políticos e culturais que fazem com que algumas vozes ocupem lugares de destaque no espaço público para a produção de sentidos sobre o passado ditatorial e para a definição 
das pautas principais na agenda de luta pelos direitos humanos. Nesse sentido, ao analisar o surgimento de H.I.J.O.S, Pablo Daniel Bonaldi (2006) aponta para a rapidez com a qual eles conseguiram conquistar espaço na esfera pública, ocupando a frente das marchas pelos direitos humanos, tomando a palavra nos principais atos de homenagem aos desaparecidos, e sendo celebrados publicamente como responsáveis por continuar a luta dos organismos de direitos humanos. Tal legitimidade social seria fruto da "herança" do prestígio e do reconhecimento que haviam acumulado os organismos de direitos humanos e que se estendia "naturalmente" à nova geração de familiares. Essa noção é compartilhada por Liliana Sanjurjo:

\begin{abstract}
A identidade política dos filhos de desaparecidos encontra assim o seu fundamento nas histórias de militância desses grupos de familiares, que se constituem como atores políticos por meio da narrativa genealógica: é através da família que se dá a transferência de legados e identidades políticas. Embora os filhos possuam trajetórias de vida bastante diversas, sentem-se, em grande medida, identificados: são antes de tudo, "filhos de uma mesma história", foram educados na luta de Madres e Abuelas (SANJURJO, 2018, p. 195).
\end{abstract}

A maior legitimidade que alguns grupos e perfis de militantes de direitos humanos têm em relação a outros delimita hierarquias no interior do movimento, visível principalmente, segundo Ludmila da Silva Catela, nos atos públicos relacionados ao "problema dos desaparecidos". Nestes, as mães, avós, filhos e filhas seriam grandes protagonistas e estariam no topo da hierarquia, seguidos pelas irmãs e irmãos e, por último, os cônjugues. Em alguns momentos, essa dinâmica poderia incluir os companheiros de militância como parte de uma "família ampliada", mas sempre em uma “posição marginal” e "pouco legitimada" (DA SILVA CATELA, 2001, p. 73-74). Virginia Vecchioli pontua que a "preeminência moral" dos familiares instauraria uma "relação hierárquica" no interior do movimento de direitos humanos: a militância fundada em uma relação de parentesco com as vítimas se contrapunha a uma militância cujo compromisso com a causa dos direitos humanos tem outro fundamento que não o "biológico", como no caso dos organismos constituídos por membros das igrejas ou vinculados a elas (MEDH 
e SERPAJ), bem como por profissionais, "comprometidos com o Direito" e com a "demanda de Justiça" (LADH, APDH e CELS) (VECCHIOL, 2005, p. 252). Como consequência desses processos, Elizabeth Jelin (2010) apontou que a experiência argentina seria um "caso extremo" do poder da posição dos familiares, pois a noção de verdade e a legitimidade da palavra chegam a estar encarnados na experiência pessoal de vitimização e nos vínculos genéticos. Entretanto, essa "força da família" implicaria paradoxalmente em uma possível exclusão de outras vozes e demandas:

Las Madres pueden haber generalizado su maternidad, con el slogan de que todos los desaparecidos son hijos de todas las Madres. Al mismo tiempo, y como efecto de esta interpretación de la noción de familia, se crea una distancia -imposible de superar- en las movilizaciones públicas: entre quienes llevan la "verdad" del sufrimiento personal y privado y aquellos que se movilizan políticamente por la misma causa, pero presumiblemente por otros motivos, que no son vistos como igualmente transparentes o legítimos. Es como si en la esfera pública del debate, la participación no es igualitaria sino estratificada de acuerdo con la exposición pública del lazo familiar; razones ideológicas, políticas o éticas no parecen tener el mismo poder justificatorio a la hora de actuar en la esfera pública, excepto "acompañando" las demandas de los/las "afectados/as directos/as" (JELIN, 2010, p. 232).

\section{A História Recente e as novas perspectivas nos estudos sobre o movimento argentino de direitos humanos}

Além das contribuições do campo de estudos da memória, notamos a partir de meados dos anos 2000, uma profusão de trabalhos que trouxeram questões sobre o movimento argentino de direitos humanos até então pouco trabalhadas, partindo de problemáticas cada vez mais específicas, e problematizando alguns tipos de senso comum que até então tinham se estabelecido. Constitui-se, então, o chamado campo da História Recente na Argentina que, apesar de dialogar com questões e com algumas metodologias parecidas com o do campo dos estudos pela memória, trouxe alguns questionamentos próprios como a questão da temporalidade e o trabalho com as fontes documentais, escritas ou orais (FRANCO; LEVIN, 2007). Devemos ressaltar que, no caso argentino, se tratam de dois campos de estudos que muitas vezes se sobrepõem e se confundem, fruto 
principalmente do fato dos dois geralmente terem como objeto de estudo a violência no passado recente argentino e as suas consequências sociais, políticas e culturais, assim como por se tratarem de dois campos interdisciplinares, com contribuições da História, da Sociologia e da Antropologia. Logo, é comum que em Programas de Pós-Graduação, publicações e eventos acadêmicos os dois campos apareçam jutos: História Recente e Memória.

Uma das questões que contribuíram para o desenvolvimento da chamada História Recente foi a constituição dos chamados arquivos da repressão e da luta pelos direitos humanos, indispensáveis para a construção da prova jurídica, com a reabertura das causas penais em 2006, que criou novas condições materiais para a investigação empírica e gerou discussões sobre a sua preservação, o seu acesso e o seu uso público por investigadores, advogados e pelas vítimas (CHAMA, SORGENTINI, 2011). Por "arquivos da repressão", devemos entender os documentos que foram acumulados e produzidos pelas forças repressivas como "provas da perseguição aos delinquentes tidos como subversivos". Já os arquivos da luta pelos direitos humanos, também registraram o funcionamento da repressão, mas através de papeis, objetos e documentos que os organismos e os indivíduos vinculados à busca pelos desaparecidos acumularam (CATELA, 2007, p. 187). Logo, tais acervos dão conta das práticas, discursos e estratégias que formaram o repertório de ação da luta pelos direitos humanos.

À possibilidade de acesso aos acervos documentais deve-se somar também o desenvolvimento da metodologia da História Oral, que passou a tomar o testemunho não apenas como um recurso que complementaria a informação oriunda das fontes escritas mais tradicionais, mas como uma produção de sentido legítimo com seus próprios termos (CHAMA, SORGENTINI, 2011). Reconheceu-se assim a riqueza das fontes orais para se aproximar da dimensão da experiência dos sujeitos, das suas perspectivas, da sua subjetividade para pensar o caráter individual e o coletivo das recordações e as diferentes temporalidades que se entrecruzam no seu relato (CARNOVALE, 2007; KOTLER, SCOCCO, 2014). Em relação aos estudos sobre o movimento argentino de direitos 
humanos, Marianela Scocco (2016) aponta que a entrevista oral contribui para que o investigador se aproxime dos sujeitos participantes de mobilizações que não tiveram suficiente representação em documentos escritos. A ausência de documentação escrita seria maior no período da ditadura, na qual os organismos agiam em uma situação de semiclandestinidade, os arquivos institucionais de alguns deles foram levados sob custódia pelas forças repressivas e a imprensa local se ocupou escassamente da cobertura de suas ações.

Nesse contexto, devemos destacar a importância de algumas inciativas institucionais de constituição de acervos documentais, escritos e orais, que foram importantes para garantir o acesso dos investigadores às fontes e assim formular novas perguntas. Uma dessas iniciativas foi o Memoria Abierta. Criado no ano 2000, trata-se de uma aliança entre organismos de direitos humanos argentinos que promove a memória coletiva sobre as violações dos direitos humanos durante a última ditadura, as ações de resistência e as lutas por verdade e justiça durante o período democrático. ${ }^{2}$ De acordo com Ana Guglielmucci, a sua criação se deu devido à demanda, por parte de alguns organismos, de criar um espaço próprio para debater seus próprios projetos de memória frente aos projetos estatais que começavam a ganhar força em Buenos Aires, no final da década de 1990, bem como de buscar soluções sobre como preservar e sistematizar os documentos que constavam em suas sedes, sem perder o controle das informações reunidas. Dessa forma, ao ser criado, o Memoria Abierta tinha como uma de suas premissas um programa de tratamento dos documentos históricos-institucionais dos acervos dos organismos de direitos humanos (GUGLIELMUCCI, 2013, p. 63-68). Atualmente, o seu Acervo Documental é composto de dois fundos. No primeiro, o "Fundo Organismos de Direitos Humanos", a instituição realizou um trabalho no fundo

\footnotetext{
2 Atualmente, o Memoria Abierta é composto por nove organismos: Asamblea Permanente por los Derechos Humanos (APDH); Asociación Civil Buena Memoria; Centro de Estudios Legales y Sociales (CELS); Comisión de Homenaje de las Víctimas de Vesubio y Puente 12; Comisión por la Memoria, Verdad y Justicia de Zona Norte; Familiares de Detenidos y Desaparecidos por Razones Políticas; Fundación Memoria Histórica y Social Argentina; Madres de Plaza de Mayo - Línea Fundadora e o Servicio Paz y Justicia (SERPAJ).
} 
documental de cada organismo a fim de garantir a sua consulta. Já o segundo, o "Fundos Memoria Abierta", pode ser consultado na sede da instituição em um dos edifícios do Espacio Memoria y Derechos Humanos, no qual antes funcionava a ESMA. Tal fundo é formado por fundos pessoais e institucionais doados para que sejam preservados e custodiados aí e por um Arquivo Oral, cujos testemunhos se referem à experiência pessoal dos entrevistados em relação aos principais processos sociais, políticos e ideológicos da segunda metade de século XX, enfatizando a mobilização social e política, o terrorismo de Estado e a luta pelos direitos humanos durante a ditadura e o período democrático (BACCI; OBERTI; SKURA, 2012; FLORES, 2017). Consequentemente, essas entrevistas permitem uma aproximação das histórias de vida com matizes mais diversos, indo além da ênfase posta na violência sofrida por cada indivíduo. Ao nosso ver, essa característica foi fundamental para que os investigadores percebessem que muitos desses entrevistados, além de vítimas, tiveram diversas possibilidades de agência histórica, dentre as quais estava a mobilização em torno dos direitos humanos.

A partir do que foi dito sobre as possibilidades de desenvolvimento de estudos sobre o movimento argentino de direitos humanos, partindo das questões da História Recente, podemos apontar algumas perspectivas que têm surgido em trabalhos recentes. A primeira delas é uma ampliação dos perfis dos militantes de direitos humanos, dos seus diferentes vínculos com a causa e das suas formas de associação, para além dos organismos de familiares que, até então, tiveram protagonismo na produção bibliográfica. Essa ampliação se deu por meio de alguns caminhos. O primeiro deles foi $o$ reconhecimento de outros perfis de vítimas do terrorismo de Estado e as possibilidades encontradas por eles para se reinserir politicamente a partir de uma reconfiguração identitária e subjetiva em torno da causa dos direitos humanos e da memória da última ditadura. De acordo com Virginia Vecchioli, a categoria de "vítima” não é a expressão direta de um dano sofrido, mas uma construção realizada a partir da intervenção de diferentes agentes dotados de saberes especializados que a produzem, objetivam, oferecem existência social e a consagram publicamente. As análises realizadas para ela 
apontam que as políticas de memória implementadas pelos sucessivos governos de um lado, e as práticas dos organismos de direitos humanos do outro, fizeram com que o entendimento sobre quem eram as vítimas do terrorismo de Estado e da ditadura variassem ao longo do tempo e com diferentes níveis de legitimidade (VECCHIOLI, 2001; 2013). Nesse quadro, algumas vítimas tiveram maior dificuldade de serem reconhecidas que outras, devido à primazia da figura do desaparecido e aos diferentes vínculos que algumas delas tiveram com a militância nas organizações das esquerdas revolucionárias, nos anos 1960 e 1970 (CANELO; GUGLIELMUCCI, 2005; LONGONI, 2007; JENSEN, 2014).

Essa invisibilização de ex-exiladas e exilados, ex-presas e presos políticos e sobreviventes dos centros clandestinos de detenção foi paulatinamente sofrendo reveses fruto do reconhecimento das suas vozes em diferentes inciativas de produção de memórias sobre a ditadura e sobre a militância, principalmente a partir da segunda metade dos anos 1990. De acordo com Marina Franco (2007), nota-se a partir de então uma revisão da figura do desaparecido, até então evocada como figura moral da vítima e caracterizada como "inocente", alheia aos processos de radicalização política. Logo, “empezó a recuperarse su identidad, y la de otras víctimas en general, en tantos actores políticos del pasado" (FRANCO, 2007, p. 46), emergindo memórias sobre as experiências nos centros clandestinos de detenção, nas prisões e no exílio. A esse processo se somou o lugar social que se abriu para diferentes perfis de vítimas no aparato estatal, a partir das políticas de memória implementadas por Néstor Kirchner, nos julgamentos, nas agências estatais e nos "espaços de memória".

Em paralelo, esses outros perfis de vítimas geraram interpretações sobre as suas respectivas experiências, as quais buscaram, de maneira geral, analisar as suas modalidades de inserção no movimento argentino de direitos humanos. Nesse quadro, as ex-exiladas e os ex-exilados foram os que até o momento geraram mais interpretações que reconhecem a importância dos direitos humanos como um possível campo para sua participação política nos diversos destinos do desterro e a sua contribuição para a instalação do tema das violações de direitos humanos cometidas pela ditadura no exterior. 
Além disso, esses trabalhos permitem analisar o caráter transnacional do movimento argentino de direitos humanos, fruto da rede de relações de solidariedade estabelecidas entre os organismos locais, organismos dos países do Cone Sul e os organismos de atuação internacional (JENSEN, YANKELEVICH, 2007; FRANCO, 2008; JENSEN, 2008, 2010; YANKELEVICH, 2010; QUADRAT, 2011; CATTOGIO, 2016b).

Os estudos sobre as ex-presas e ex-presos políticos, por outro lado, apontam para a sua dificuldade de se organizar coletivamente em torno de uma experiência em comum, após a sua detenção. Por outro lado, apontam que, durante a ditadura, eles participaram do processo de denúncias humanitárias, através de contatos com organismos internacionais, como a Cruz Vermelha, e do trabalho realizado pelos organismos na Argentina de solidariedade aos presos políticos e seus familiares (GUGLIELMUCCI, 2005; MERENSON, 2014). Já os sobreviventes dos centros clandestinos de detenção são os que mais tardiamente receberam a atenção dos investigadores sobre a memória e a história recente. ${ }^{3}$ Entretanto, análises recentes têm apontado que a sua inserção no movimento argentino de direitos humanos não se iniciou apenas com a sua participação na Comisión Nacional sobre la desaparición de Personas (CONADEP), em 1984, e no Juicio a las Juntas, em 1985, não tendo se restringido apenas à possibilidade de dar testemunho. Desde a última ditadura, uma vez em liberdade, os sobreviventes colaboraram ativamente com organismos de direitos humanos na Argentina e no exterior, e se inicialmente o testemunho foi a sua principal forma de intervenção, alguns deles logo encontraram

\footnotetext{
${ }^{3}$ Durante a mais recente ditadura argentina, as prisões e os centros clandestinos de detenção formaram um continuum repressivo, um demonstrativo de que as Forças Armadas montaram uma articulação entre as instâncias repressivas legais e ilegais. O Decreto 1.209, de 06 de julho de 1976, estabeleceu a coordenação dos organismos penitenciários de nível nacional e provincial para o alojamento e traslados de detidos, processados e condenados, assim como de indivíduos postos à disposição do PEN. Isto significava que podiam permanecer presos sem a necessidade de ser submetidos a qualquer processo judicial. Além de representarem diferentes facetas de um mesmo plano repressivo, nas prisões também foram adotados a tortura e o desaparecimento. No total, 157 presos políticos desapareceram após terem aparentemente ganhado a liberdade. A grande diferença é que, ao chegar às prisões, os indivíduos recobravam uma existência pública e formal, garantindo inclusive o direito de comunicar-se com familiares e advogados. Baseando-se nessa diferença, no nosso trabalho, optaremos por trabalhar a trajetória daqueles que, mesmo posteriormente tendo passado por um dos cárceres legais da ditadura, atravessaram a experiência do desaparecimento em um dos centros clandestinos. Ver: MEMORIA ABIERTA, p. 34-36.
} 
possibilidades de se organizar coletivamente para desenvolver estratégias de ação, uma experiência que, com o final da ditadura, resultaria na constituição de espaços próprios, como, por exemplo, a Asociación de Ex Detenidos Desaparecidos (AEDD), em 1984 (AYALA, 2019; LAMPASONA, 2017; MESSINA, 2012; RAMA, 2015; TAHIR, 2011; TELLO, 2015; GONZALEZ TIZON, 2016, 2018; TOLENTINO, 2019).

Para além dos diferentes perfis de vítimas da repressão, alguns trabalhos reconstruíram a participação de outros organismos no movimento argentino pelos direitos humanos, como, por exemplo, o CELS (BALARDINI, 2015; BASUALDO, 2019; GANDULFO, 2014; GONZALEZ TIZÓN, 2018) e a LADH (CASOLA, 2015; VECCHIOLI, 2012), assim como de outros perfis de militantes, tais como os religiosos de origem católica ou judia (KAHAN, 2014; CATTOGIO, 2016a), os advogados (MEMORIA ABIERTA, 2010; GONZALEZ TIZÓN, 2016; VECCHIOLI, 2017; CHAMA, 2014, 2016), e militantes com vínculos com organizações da esquerda revolucionária, como a Vanguardia Comunista (GONZALEZ TIZÓN, 2018), o Ejército Revolucionario del Pueblo do Partido Revolucionario de los Trabajadores (PRT-ERP) (EIDELMAN, 2009) e Montoneros (CONFINO, 2018). O reconhecimento da participação de militantes vinculados com partidos da esquerda ou com grupos da esquerda revolucionária em organismos de direitos humanos é importante para problematizarmos uma noção central nos estudos sobre o movimento de direitos humanos na década de 1980, que era o seu suposto distanciamento dos partidos políticos dos anos 1970. Permite ainda analisar a trajetória de militantes da esquerda que encontraram no movimento pelos direitos humanos um novo espaço de atuação, uma vez que seus partidos haviam sido atingidos pela repressão, incorporando uma nova linguagem, novas práticas e novas estratégias de ação (MARKARIAN, 2006).

As análises sobre outros perfis de militantes contribuem também para um questionamento sobre a temporalidade da mobilização em torno dos direitos humanos, sobretudo das suas genealogias. Como afirmamos anteriormente, a narrativa histórica consolidada sobre a história do movimento argentino pelos direitos humanos produzida aponta para um vazio entre a criação da LADH, em 1975, e o surgimento da APDH, em 
1975. Entretanto, essa produção traz uma série de antecedentes importantes para o movimento de direitos humanos que se formou e se desenvolveu antes dos anos $1975 \mathrm{e}$ 1976, sobretudo as organizações de defesa e solidariedade com os presos políticos, existentes durante o período da ditadura militar autoproclamada Revolución Argentina (1966-1973). Alguns ativistas vinculados a essas experiências e organizações, particularmente advogados, tiveram protagonismo na origem e na constituição de organizações no país, e principalmente no exterior, denunciando o terrorismo de Estado a partir do exílio (EIDELMAN, 2009, p. 18).

A segunda perspectiva é o desenvolvimento de histórias locais considerando "comunidades locais", na sua maioria localizadas territorial, simbólica e/ou politicamente distantes da capital, Buenos Aires, e dos seus processos centrais (DEL PINO; JELIN, 2003, p. 9). Se os estudos sobre o exílio permitiram pensar no caráter transnacional da luta pelos direitos humanos, as histórias locais questionam a temporalidade do acionar do movimento argentino de direitos humanos, ao demonstrar que existiram lógicas próprias de surgimento e de constituição de organismos de direitos humanos de acordo com as possibilidades locais de mobilização e das características locais do acionar repressivo. Questionam assim uma tentativa de se "nacionalizar" uma história que tem matizes e contradições quando analisada a partir de outros espaços, para além da capital, Buenos Aires. Nesse sentido, ao analisar o caso de Santa Fe, na província de Rosario, Luciano Alonso (2011) analisa alguns antecedentes imediatos locais de defesa dos direitos humanos nas ações realizadas por distintos coletivos, concentradas principalmente no período entre 1969-1973, em função do crescimento e transformação qualitativa da repressão. Algo parecido aponta Ana Carolina Solis (2014) em relação ao caso de Córdoba: uma conformação cedo de agrupamentos pela defesa dos presos políticos, ligados ao processo de radicalização política e ideológica do final dos anos sessenta e princípio dos anos setenta e também às variações do esquema repressivo, incluindo a antecipada implementação de práticas compatíveis com o Terrorismo de Estado antes do golpe de 24 de março de 1976. 
Os trabalhos de Marianela Scocco $(2016,2018)$ demonstram que as lógicas de constituição de grupos locais de organismos de direitos humanos de expressão nacional nem sempre acompanharam a temporalidade do seu surgimento em Buenos Aires. A sua análise aponta, por exemplo, que as filiais de Rosario de Avós e Mães da Praça de Maio foram fundadas apenas em 1984 e em 1985, respectivamente, quando a última ditadura já havia terminado. Ao analisar o caso do movimento de direitos humanos na província de Tucumán, Rubén Kotler (2018) demonstra que as suas origens se relacionam às primeiras denúncias de sequestro e desparecimento forçado de pessoas, fruto do acionar da Triple A, em 1974, e da institucionalização do Operativo Independencia, em 1975. Além disso, a sua hipótese central é de que diferentemente de outras organizações similares do país, as organizações de direitos humanos da província tucumana centraram suas ações em enfrentamento a Antonio Domingo Bussi, primeiro governador durante os primeiros anos da última ditadura, que, em seguida, voltou a se reeleger na democracia, entre 1995 e 1999.

A terceira perspectiva é uma problematização sobre o papel desempenhado pelo movimento argentino pelos direitos humanos e pela pauta dos direitos humanos durante os últimos anos da ditadura e a chamada "transição democrática". Nos anos 1980, os primeiros estudos sobre o movimento de direitos humanos afirmaram que seu papel central na derrocada da última ditadura, na instauração de um "novo pensamento republicano" e em colocar o tema dos desaparecidos como central nas discussões públicas. Entretanto, os artigos da coletânea dirigida por Claudia Feld e Marina Franco (2015) problematizaram tais noções ao questionarem a própria noção de "transição democrática", como um corte institucional abruto ocorrido no momento em que Alfonsín se elegeu, em dezembro de 1983. Na conclusão do livro, Claudia Feld e Marina Franco apontam algumas características abordadas pelos diversos autores sobre os primeiros momentos da redemocratização, em especial o ano de 1984, dentre as quais estariam as fortes continuidades com o passado da ditadura e do período anterior a ela, indicando que o corte institucional e o clima de repudio à ditaura da transição não significaram uma mudança imediata das percepções públicas sobre o ocorrido na década de 1970. Da mesma 
maneira, a convivência na cena pública com absoluta legitimidade de um amplo arco de valores e representações sobre o passado e o presente que estavam em disputa. Em relação à legitimidade das pautas do movimento de direitos humanos, elas apontam para as tensões entre os organismos de direitos humanos e na cena pública sobre quem eram os desaparecidos e acerca da natureza desse delito, assim como a coexistência do discurso das "violações de direitos humanos" com outros que não questionavam a legitimidade do acionar das Forças Armadas. Já o livro de Marina Franco (2018) aponta para o caráter indeterminado e relativamente aberto do processo que levou à investigação e justiça aos crimes cometidos durante a última ditadura, tendo em vista que a demanda dos organismos de direitos humanos da necessidade de investigar e buscar justiça era minoritária frente à maioria dos atores políticos da época que se mostravam dispostos a "encerrar o passado" e à legitimidade que ainda tinham os militares em impor estratégias de silêncio e de negativas a prover informação.

Nos primeiros anos da democracia, o movimento de direitos humanos passou a exercer um papel central na cena pública, participando, por exemplo, da investigação da CONADEP e influenciando na metodologia utilizada em sua investigação, na sistematização de dados e na redação do seu relatório final, como demonstrou Emilio Crenzel (2008). Além disso, foram importantes para instalar socialmente a questão do retorno dos exilados e suas questões específicas (LASTRA, 2016). Os organismos tiveram um papel importante na abertura de causas contra militares envolvidos na repressão, nos debates sobre como eles deveriam ser julgados e muitos de seus militantes foram testemunhas centrais durante o julgamento às juntas de comandantes militares que governaram a Argentina durante a última ditadura, o Juicio a las Juntas (GONZALEZ TIZON, 2018; GALANTE, 2019). Por outro lado, em todas essas iniciativas as suas possibilidades de conduzir os processos em torno da luta pelos direitos humanos foram limitadas pelas disputas em torno do lugar que o passado ditatorial ocuparia na democracia. 
De acordo com Elizabeth Jelin, o período iniciado com o final da Guerra das Malvinas, em 1982, até o ano de 1984 foi "um momento de inovação e experimentação, de debates e de busca de propostas de saídas institucionais para o novo governo" (JELIN, 2015, p. 219). Logo, a narrativa que nos anos 1980 apontou o movimento de direitos humanos como um ator político e social central para o fim da ditadura e para a revalorização dos valores democrático na nova democracia tem sido problematizada. Através da análise de documentos produzidos pela imprensa e pelos próprios organismos, produzem-se histórias com outras nuances, que apontam a transição para a democracia e os anos que a seguiram como um período marcado por incertezas e pela permanência no espaço público de alguns discursos e representações produzidos ou reivindicados pela ditadura, que tiveram efeitos diretos no repertório de ação dos organismos de direitos humanos e no reconhecimento de suas demandas.

\section{Considerações finais}

Na década de 1980, logo após o final da última ditadura civil-militar argentina, o movimento de direitos humanos tornou-se objeto de análises das Ciências Sociais na Argentina. Tais análises produziram uma narrativa histórica pautada na experiência de mobilização do chamado "oito organismos históricos", tomando o período da última ditadura como um ponto inicial para as lutas em torno dos direitos humanos. Além disso, apontaram que a causa dos direitos humanos se distanciava do mundo da política dos partidos e das organizações da esquerda revolucionária dos anos 1960 e 1970. Reforçavam também a noção de que, assim como o desaparecimento forçado de pessoas implementado pela última ditadura havia sido uma novidade na história da violência política no país, também era a inédita a mobilização principalmente de familiares que resistiam às tentativas de silêncio e de esquecimento impostos por esta modalidade repressiva.

A partir dos anos 2000, fruto do desenvolvimento dos campos dos estudos das memórias e da História Recente, e das possibilidades de se consultar acervos de arquivos 
orais e de arquivos produzidos por organismos de direitos humanos, notamos o surgimento de novos questionamentos sobre o movimento argentino de direitos humanos, seus discursos, seus repertórios de ação e os perfis de seus militantes. Paulatinamente, o protagonismo dos familiares passou a ser problematizando, interrogando as razões da maior legitimidade alcançada por suas vozes no espaço público e recuperando outras formas de vinculação com a causa dos direitos humanos na Argentinas. O reconhecimento de que advogados, religiosos, ex-presos políticos, ex-exilados e sobreviventes dos centros clandestinos de detenção também participaram da denúncia humanitária, contribuíram com organismos de direitos humanos no país e no exterior e formaram seus próprios espaços de militância permitem-nos afirmar que o movimento de direitos humanos na Argentina não se resume à experiência dos familiares. Eles desempenharam um papel importante nos últimos quarenta anos, mas sempre em diálogo ou em conflito com outros atores que também participaram dos processos de produção de sentidos, demandas e práticas em torno do passado recente. Logo, podemos afirmar a partir da revisão bibliográfica proposta por este artigo que o movimento argentino de direitos humanos é um movimento social heterogêneo, no qual convivem experiências diversas e múltiplos horizontes de expectativas, e cujas práticas e discursos estão em constante reconfiguração de acordo com o tratamento que o terrorismo de Estado e suas vítimas recebem no presente.

\section{Referências Bibliográficas}

ALONSO, Luciano. "El surgimiento del movimiento argentino por los derechos humanos en perspectiva comparada". Páginas, revista digital de la Escuela de Historia - UNR. Año 1, pp. 87-109, Rosario, 2008.

"Razones, modos y efectos de una historia del movimiento por los Derechos Humanos”. In: CERNADAS, Jorge; LVOVICH, Daniel (comps.). Historia, ¿para qué?: revisitas a una vieja pregunta. Buenos Aires: Prometeo Libros, 2010a. 
"Integración e impacto del movimiento de derechos humanos en una ciudad del litoral argentino". In: BOHOSLAVSKY, Ernesto [et.al.]. Problemas de historia reciente del Cono Sur, vol. II. Buenos Aires: Prometeo Libros, $2010 \mathrm{~b}$.

Luchas en plazas vacías de sueños: movimiento de derechos humanos, orden loca y acción antisistémica en Santa Fe. Rosario: Prohistoria Ediciones, 2011.

."El estudio de las luchas pro derechos humanos en Argentina: problemas de enfoque en torno a la categoría de movimiento social". In: FLIER, Patricia. Dilemas, apuestas y reflexiones teórico-metodológicas para los abordajes en Historia Reciente. La Plata: EDULP, 2014.

AYALA, Mario. "Los exiliados argentinos en Venezuela. Solidaridad, denuncia y construcción de redes regionales de derechos humanos (1976-1981)". In: JENSEN, S.; LASTRA, S (eds.). Exilios: Militancia y represión. Nuevas fuentes y nuevos abordajes de los destierros de la Argentina de los años setenta. La Plata: Edulp, 2014. Disponível em: http://www.memoria.fahce.unlp.edu.ar/libros/pm.371/pm.371.pdf Acesso em: 16 jul. 2019.

. "Reaparecer en el exilio': experiencias de militantes argentinos sobrevivientes de desaparición forzada en Venezuela (1979-1984)". In: Tempo, vol. 25, n. 2, pp. 470-495, Niterói, jun. /ago. 2019.

BACCI, Claudia; OBERTI, Alejandra; SKURA, Susana. "Testimonios en archivos: nuevas perspectivas". História Oral: Revista da Associação Brasileira de História Oral, v. 15. n. 2, pp. 33-49, São Paulo, 2012.

BALARDINI, Lorena. Estrategias de producción de información de las organizaciones de derechos humanos en Argentina. Los usos de la sistematización y la estadística en la búsqueda de verdad y justicia. Tese (Magister en Ciencias Sociales) - Facultad de Ciencias Sociales. Universidad de Buenos Aires, 2015.

BALÉ, Cinthia. Memoria e identidad durante el kirchnerismo: la "reparación" de legajos laborales de empleados estatales desaparecidos. La Plata: Universidad Nacional de La Plata (Entre los libros de la buena memoria; 11), 2018.

BAUER, Caroline Silveira. Brasil e Argentina: ditaduras, desaparecimento e políticas de memória. Porto Alegre: Medianiz, 2012.

BASUALDO, Guadalupe. Movilización internacional en dictadura: la visita de la CIDH y la creación del CELS. Buenos Aires: Editorial Teseo, 2019.

BISQUERT, Jacquelina; LVOVICH, Daniel. La cambiante memoria de la dictadura: discursos públicos, movimientos sociales y legitimidad democrática. Buenos Aires: Biblioteca Nacional, 2008. 
BONALDI, Pablo Daniel. "Hijos de desaparecidos. Entre la construcción de la política y la construcción de la memoria". In: JELIN, Elizabeth; SEMPOL, Diego. El pasado en el futuro: los movimientos juveniles. Buenos Aires: Siglo XXI Ed., 2006.

CANELO, Brenda; GUGLIELMUCCI, Ana. "(Re)aparecer en democracia: silencios y pasados posibles". In: Anuario de Estudios de Antropología Social, pp. 175-186, Buenos Aires, septiembre de 2005. Disponível em: http://cas.ides.org.ar/files/2012/09/Anuario-EAS-2005.pdf (Última visualização: 06/04/2019).

CARNOVALE, Vera. "Apuntes y problemas de los testimonios en la reconstrucción del pasado reciente en la Argentina". In: FRANCO, Marina; LEVÍN, Florencia. Historia reciente: perspectivas y desafíos para un campo en construcción. Buenos Aires: Paidós, 2007.

CASOLA, Natalia. El PC argentino y la dictadura militar. Militancia, estrategia política y represión estatal. Buenos Aires: Imago Mundi, 2015.

CATOGGIO, María Soledad. Los desaparecidos de la iglesia: El clero contestatario frente a la dictadura. Buenos Aires: Siglo XXI Eds., 2016a.

CATOGGIO, María Soledad. "Integración latinoamericana: contra la coordinación represiva y por una policía regional de los derechos humanos. El caso CLAMOR". In: FUNES, Patricia. Revolución, dictadura y democracia. Lógicas militantes y militares en la historia argentina en el contexto latinoamericano. Buenos Aires: Imago Mundi, 2016b.

DA SILVA CATELA, Ludmila. Situação-limite e memória. A reconstrução do mundo dos familiares de desaparecidos da Argentina. São Paulo: Hucitec, Anpocs, 2001.

“Apagón en el Ingenio, escrache en el Museo. Tensiones y disputas entre memorias locales y memorias oficiales en torno a un episodio de represión de 1976". In: JELIN, Elizabeth; PINO, Ponciano del. Luchas locales, comunidades e identidades. Buenos Aires: Siglo XXI Editores, 2004.

"Etnografía de los archivos de la represión en la Argentina". In: FRANCO, Marina; LEVÍN, Florencia. Historia reciente: perspectivas y desafíos para un campo en construcción. Buenos Aires: Paidós, 2007.

"Derechos humanos y memoria. Historia y dilemas de una relación particular en Argentina". In: Teoria e Cultura, v. 3, n. 1/2, pp. 09-20, Juiz de Fora jan./dez. 2008.

"Pasados en conflicto. De memorias dominantes, subterráneas y denegadas". In: BOHOSLAVSKY, Ernesto [et.al.]. Problemas de historia reciente del Cono Sur, vol. I. Buenos Aires: Prometeo Libros, 2010.

“"Lo que merece ser recordado...'. Conflictos y tensiones en torno a los proyectos públicos sobre los usos del pasado en los sitios de memoria". In: Clepsidra. Revista Interdisciplinaria de Estudios sobre Memoria, nº 2, pp. 28-47, Buenos Aires, octubre 2014. 
CERRUTI, Gabriela. "La historia de la memoria". In: Puentes. Revista de la Comisión Provincial por la Memoria. La Plata, ano 2, n.3, marzo 2001.CHAMA, 2014.

CHAMA, Mauricio Sergio. "Activismo social, militancia política y radicalización en los años sesenta: la experiencia de la Comisión de Familiares de Detenidos (COFADE)". In: TORTTI, María Cristina (dir.). La nueva izquierda argentina (1955-1976). Socialismo, peronismo y revolución. Rosario: Prohistoria ediciones, 2014.

Compromiso político y labor profesional: estudios sobre psicólogos y abogados en los primeros setenta. La Plata: Universidad Nacional de La Plata, 2016a. CHAMA, Mauricio; SORGENTINI, Hernán. "Momentos, tendencias e interrogantes de la producción académica sobre la memoria del pasado argentino. In: Nuevo Mundo Mundos Nuevos, Questions du temps présent, 2011. Disponível em: https://journals.openedition.org/nuevomundo/62176 Acesso em: 29/04/2019.

CONFINO, Hernán. La Contraofensiva Estratégica de Montoneros. Entre el exilio y la militancia revolucionaria (1976-1980). Tese (Doutorado em História) - Instituto de Altos Estudios Sociales. Universidad Nacional de General San Martín, 2018.

CRENZEL, Emilio. La historia política del Nunca Más: la memoria de las desapariciones en la Argentina. Buenos Aires: Siglo XXI Eds., 2008.

"Hacia una historia de la memoria de la violencia y los desaparecidos en Argentina". In: CRENZEL, Emilio; MONTAÑO, Eugenia Allier. Las luchas por la memoria en América Latina. Historia reciente y violencia política. México: Bonilla Artigas Editores: UNAM, Instituto de Investigaciones Sociales, 2015.

CUETO RUA, Santiago. "El campo de los derechos humanos y la memoria. Miradas desde la sociología, la historia y la antropología". In: Dossier "El campo de los derechos humanos y la memoria. Miradas desde la sociología, la historia y la antropología", Mayo 2017. Disponível em: http://www.historiapolitica.com/dossiers/dossier-el-campo-de-los-derechos-humanos-y-lamemoria-miradas-desde-la-sociologia-la-historia-y-la-antropologia/ Acesso em: 04 maio 2019.

. "Apuntes para el pensar el campo de derechos humanos y la memoria". KAHAN, Emanuel; CUETO RÚA, Santiago; RODRÍGUEZ, Laura García (coords.). Memoria y violencia en el siglo XX: Horizontes de un proyecto de investigación. La Plata: Universidad Nacional de La Plata. Facultad de Humanidades y Ciencias de la Educación, 2018a. Disponível em: http://www.libros.fahce.unlp.edu.ar/index.php/libros/catalog/104 Acesso em: 11 jun. 2019.

Ampliar el círculo de los que recuerdan: La inscripción de la Comisión Provincial por la Memoria en el campo de los derechos humanos y la memoria (1999-2009). Los Polvorines: Universidad Nacional de General Sarmiento; La Plata: Universidad Nacional de La Plata. Facultad de Humanidades y Ciencias de la Educación; Posadas: Universidad Nacional de Misiones, 2018b. Disponível em: http://www.memoria.fahce.unlp.edu.ar/libros/pm.677/pm.677.pdf Acesso em 11 jun. 2019. 
DEL PINO, Ponciano; JELIN, Elizabeth (comps.). Luchas locales. Comunidades e identidades. Buenos Aires: Siglo XXI, 2003.EIDELMAN, 2009.

EIDELMAN, Ariel. "El PRT-ERP y la lucha por la libertad de los presos políticos, 1971-1973". In: Sociohistórica, n. 25, pp. 13-39, 2009.

FELD, Claudia. "Preservar, recuperar, ocupar. Controversias memoriales en torno a la ex ESMA (1998-2013)”. In: Rev. Colomb. Soci., 40(1), pp. 101-131, ene,-jun. 2017.

FELD, Claudia; FRANCO, Marina. "Introducción”; "Democracia y derechos humanos en 1984, ¿hora cero?". In: FELD, Claudia; FRACO, Marina (dir.). Democracia, hora cero: actores, políticas y debates en los inicios de la postdictadura. Buenos Aires: Fondo de Cultura Económica, 2015.

FLORES, Celina. "El testimonio en el archivo, voces entre el pasado y el presente a partir de la experiencia de Memoria Abierta". Disponível em: <http://www.alaarchivos.org/wpcontent/uploads/2017/12/3a.-Celina-Flores.pdf>. Acesso em: 30 ago.2018.

FRANCO, Marina. "Sentidos y subjetividades detrás del discurso: reflexiones sobre las narrativas del exilio producidas en entrevistas orales". In: Anuario de Estudios Americanos, vol. 64, n. 1, pp. 37-62, Sevilla, enero-junio 2007.

XXI Eds., 2008.

. El exilio: argentinos en Francia durante la dictadura. Buenos Aires: Siglo

"Do terrorismo de Estado à violência estatal: Problemas históricos e historiográficos no caso argentino". In: MOTTA, Rodrigo Patto Sá (org.). Ditaduras militares: Brasil, Argentina, Chile e Uruguai. Belo Horizonte: Editora UFMG, 2015.

El final del silencio: dictadura, sociedad y derechos humanos en la transición: Argentina, 1979-1983. Buenos Aires: Fondo de Cultura Económica, 2018. FRANCO, Marina; LEVÍN, Florencia. "El pasado cercano en clave historiográfica". In: FRANCO, Marina; LEVÍN, Florencia. Historia reciente: perspectivas y desafíos para un campo en construcción. Buenos Aires: Paidós, 2007.

GALANTE, Diego. El Juicio a las Juntas: Discursos entre política y justicia en la transición argentina. La Plata: Universidad Nacional de La Plata, 2019.

GANDULFO, Juan. "El caso de las tumbas de N.N. en Grand Bourg”. La justicia y los organismos de derechos humanos en transición a la democracia. Tese (Mestrado em Ciências Sociais) Instituto de Desarrollo Económico y Social, Universidad Nacional de General Sarmiento. Buenos Aires, 2014.GUGLIELMUCCI, 2005. 
GINZBERG, Victoria. “Todo está guardado en la memoria”. Página/12, 20 jun. 2007. Disponível em: https://www.pagina12.com.ar/diario/elpais/1-86854-2007-06-20.html Acesso em: 31 jan. 2020.

GONZÁLEZ BOMBAL, Inés. "Derechos humanos: la fuerza del acontecimiento". In: VERÓN, Eliseo. El discurso político. Buenos Aires: Hachette, 1987.GUGLIELMUCCI, 2013.

GONZÁLEZ TIZÓN, Rodrigo. “'Cada voz que se alce puede salvar una vida en Argentina'. La producción testimonial de los sobrevivientes de los Centros Clandestinos de Detención en el marco de la Comisión Argentina por los Derechos Humanos". In: Papeles de Trabajo, vol. 10, n.17, pp. 160-182, Buenos Aires, 2016.

. Militancia humanitaria y testimonio. Los sobrevivientes de 'El Vesubio' y la denuncia de los crímenes de la última dictadura (1978-2016). Tese (Doutorado em História) Instituto de Altos Estudios Sociales, Universidad de General San Martín. Buenos Aires, 2018

GUGLIELMUCCI, Ana. La consagración de la memoria: una etnografía acerca de la institucionalización del recuerdo sobre los crímenes del terrorismo de Estado. Buenos Aires: Antropofagia, 2013.

JELIN, Elizabeth. "La política de la memoria: el movimiento de derechos humanos y la construcción democrática en la Argentina”. In: ACUÑA, Carlos H [et.al.]. Juicio, Castigos y Memorias. Derechos humanos y justicia en la política argentina. Buenos Aires: Ediciones Nueva Visión, 1995.

Los trabajos de la memoria. Buenos Aires: Siglo XXI Editores, 2001.

. "Los derechos humanos y la memoria de la violencia política y la represión: la construcción de un campo nuevo en las ciencias sociales". In: Estudios Sociales, n. 27, segundo semestre 2004.

"Los derechos humanos entre el Estado y la sociedad". In: SORIANO, Juan. Nueva historia argentina, tomo X, Dictadura y democracia (1976-2001). Buenos Aires: Sudamericana, 2005.

“¿Víctimas, familiares o ciudadano/as? Las luchas por la legitimidad de la palabra". In: CRENZEL, Emilio (coord.). Los desaparecidos en la Argentina: memorias, representaciones e ideas: 1983-2008. Buenos Aires: Biblos, 2010.

"Militantes y combatientes en la historia de las memorias: silencios, denuncias y reivindicaciones". In: DURÁN, Valeria; HUFFSCHMID, Anne (org.). Topografías conflictivas: memorias, espacios y ciudades en disputa. Buenos Aires: Nueva Trilce, 2012.

"Certezas, incertidumbres y búsquedas: el movimiento de derechos humanos en la transición". In: FELD, Claudia; FRACO, Marina (dir.). Democracia, hora cero: actores, políticas y debates en los inicios de la postdictadura. Buenos Aires: Fondo de Cultura Económica, 2015. 
La lucha por el pasado: Cómo construimos la memoria social. Buenos Aires:

Siglo XXI Eds., 2017. JENSEN, 2008.

JENSEN, Silvina. La provincia flotante. El exilio argentino en Cataluña (1976-2006). Barcelona: Fundación Casa América Catalunya, 2008.

Los exiliados. La lucha por los derechos humanos durante la dictadura. Buenos Aires: Sudamericana, 2010.

"Memorias lights, memorias anestesiadas. Reflexiones acerca de los olvidos del exilio en el relato público y social de los setenta en la Argentina”. In: FLIER, Patricia G.; LVOVICH, Daniel (cords.). Los usos del olvido: recorridos, dimensiones y nuevas preguntas. Rosario: Prohistoria Ediciones, 2014.

JENSEN, Silvina; YANKELEVICH, Pablo (comps.). Exilios: destinos y experiencias bajo la dictadura militar. Buenos Aires: Libros del Zorzal, 2007.KAHAN, 2014.

KAHAN, Emmanuel Nicolás. Recuerdos que mienten un poco. Vida y memoria de la experiencia judía durante la última Dictadura Militar. Buenos Aires: Prometeo, 2014.

KOTLER, Rubén. Huella de la memoria en la resistencia antibussista. Historia del movimiento de derechos humanos en Tucumán 1976-1999. Buenos Aires: Imago Mundi, 2018.

KOTLER, Rubén Isidoro; SCOCCO, Marianela. "Estudio introductorio: los orígenes del movimiento de derechos humanos en la periferia argentina. Un mapa por trazar". In: KOTLER, Rubén Isidoro (comp.). En el país del sí me acuerdo. Los orígenes nacionales e internacionales del movimiento de derechos humanos argentina: de la dictadura a la transición. Buenos Aires: Ediciones Imago Mundi, 2015.

LAMPASONA, Julieta. Entre la desaparición y la (re-) aparición. Un análisis de las inscripciones biográficas de la experiencia de la (propia) desaparición en los sobrevivientes de los Centros Clandestinos de Detención en la Argentina. Tese (Doutorado em Ciências Sociais) Facultad de Ciencias Sociales, Universidad de Buenos Aires. Buenos Aires, 2017.

LARRALDE ARMAS, Florencia. "Cartografiar las marcas: intervenciones, disputas y transgresiones en el Espacio para la Memoria, Ex ESMA". In: Kamchatka - Revista de análisis cutlural, n. 13, pp. 163-194, junio 2019.

LASTRA, María Soledad. Volver del exilio: historia comparada de las políticas de recepción en las postdictaduras de la Argentina y Uruguay (1983-1989). La Plata: Universidad Nacional de La Plata, 2016.

LEIS, Héctor Ricardo. El movimiento por los derechos humanos y la política argentinal 1 y 2. Buenos Aires: Centro Editor de América Latina, 1989. 
LONGONI, Ana. Traiciones. La figura de traidor en los relatos acerca de los sobrevivientes de la represión. Buenos Aires: Editorial Normal, 2007.

LORENZ, Federico. “¿De quién es el 24 de marzo? Las luchas por la memoria del golpe del " 76 ”. In: JELIN, Elizabeth (comp.). Las conmemoraciones: las disputas en las fechas "in-felices". Buenos Aires: Siglo XXI Editores, 2002.

LVOVICH, DANIEL; BISQUERT, Jaquelina. La cambiante memoria de la dictadura: discursos públicos, movimentos sociales y legitmidad democrática. Buenos Aires: Biblioteca Nacional, 2008.

MARKARIAN, Vania. Idos y recién llegados. La izquierda uruguaya en el exilio y las redes transnacionales de derechos humanos, 1967-1984. Montevideo: Correo del Maestro: La VasijaCentro de Estudios Interdisciplinarios Uruguayo: Universidad de la República, 2006.

MEMORIA ABIERTA. Abogados, derecho y política. Buenos Aires: Memoria Abierta, 2010. . “...y nadie quería saber". Relatos sobre violencia contra las mujeres en el terrorismo de Estado en Argentina. Buenos Aires: Memoria Abierta, 2012.

MERENSON, Silvina. Y hasta el silencio en tus labios: memorias de las ex presas políticas del Penal de Villa Devoto en el trascurso de la última dictadura militar en la Argentina. La Plata: Al Margen, 2014.

MESSINA, Luciana. Políticas de la memoria y construcción de memoria social. Acontecimientos, actores y marcas de lugar. El caso del ex centro clandestinos de detención 'Olimpo"'. Tese (Doutorado em Antropologia) - Facultad de Filosofía y Letras. Universidad de Buenos Aires, 2010.

- "Reflexiones en torno a la práctica testimonial sobre la experiencia concentracionaria en Argentina”. In: Sociedad y Economía, n. 23, p. 37-58, Cali, 2012.

"Lugares y políticas de la memoria: a propósito de las tensiones en la calificación de las víctimas". In: Clepsidra. Revista Interdisciplinaria de Estudios sobre Memoria, $\mathrm{n}^{\circ}$ 2, pp. 66-79, Buenos Aires, octubre 2014.

"Reflexiones sobre la articulación estado-sociedad civil en las políticas de la memoria en Argentina". In: Revista Memória em Rede, Pelotas, v. 8, n. 15, pp. 109-136, Pelotas, Jul./Dez. 2016.

"Lugares y políticas de la memoria: notas téorico-metodológicas a partir de la experiencia argentina”. In: Kamchatka - Revista de análisis cutlural, n. 13, pp. 59-77, junio 2019. 
MOMBELLO, Laura Cecilia. "La Capital de los Derechos Humanos". In: JELIN, Elizabeth; PINO, Ponciano del. Luchas locales, comunidades e identidades. Buenos Aires: Siglo XXI Editores, 2004.

PEREYRA, Sebastián. ¿La lucha es una sola?: la movilización social entre la democratización y el neoliberalismo. Buenos Aires: Biblioteca Nacional, 2008.

QUADRAT, Samantha. "A emergência do tema dos direitos humanos na América Latina". In: FICO, Carlos; FERREIRA, Marieta de Moraes; ARAÚJO, Maria Paula; QUADRAT, Samantha Viz. Ditadura e democracia na América Latina: balanço histórico e perspectivas. Rio de Janeiro: Editora FGV, 2008.

. "Da Argentina para o Brasil: de uma ditadura a outra". In: QUADRAT, Samantha Viz (org.). Caminhos cruzados: história e memorias dos exílios latinoamericanos no século XX. Rio de Janeiro: Editoria FGV, 2011. RABOTNIKOF, 2008.

. "Em busca dos arquivos das ditaduras do Cone Sul: desafios e perspectivas". In: ARAUJO, Maria Paula; FICO, Carlos; GRIN, Monica (orgs.). Violência na história: Memória, trauma e reparação. Rio de Janeiro: Ponteio, 2012.

RAMA, Cristian. Sobreviviendo: Experiencias en el marco del proceso de sobrevivientes de los centros clandestinos de detención de la última dictadura militar. Tese (Licienciatura em História) - Facultad de Filosofia y Letras, Universidad de Buenos Aires. Buenos Aires, 2015SANJURJO, Liliana Lopes. Sangue, identidade e verdade: Memórias sobre o passado ditatorial na Argentina. São Carlos: EDUFScar, 2018.

SCOCCO, Marianela. El viento sigue soplando. Los Orígenes de Madres de Plaza 25 de Mayo de Rosario (1977-1985). Rosario: Editorial Último Recurso, 2016.

La conformación del movimiento de derechos humanos de Rosario (19701985). Tese (Doutorado em História) - Facultad de Humanidades y Artes. Universidad Nacional de Rosario, 2018.

SIKKINK, Kathryn. "A Emergência, Evolução e Efetividade da Rede de Direitos Humanos da América Latina". In: JELIN, Elizabeth; HERSHBERG, Eric (orgs.). Construindo a Democracia: Direitos Humanos, Cidadania e Sociedade na América Latina. São Paulo: Editoria da Universidade de São Paulo, 2006.

SOLIS, Ana Carol. "De las comisiones a los organismos en Córdoba: derechos humanos, dictadura y democratización". In: KOTLER, Rubén Isidoro. En el país del sí me acuerdo. Los orígenes nacionales e internacionales del movimiento de derechos humanos argentino: de la dictadura a la transición. Buenos Aires: Imago Mundi, 2014.

TAHIR, Nadia. Les associations de victimes de la dictadura: politiques de droits de l'homme et devoir de mémoire en Argentine (1976-2007). Thèse (Docteur en Études Romanes/Espagnol) École Doctorale IV: Civilisations, cultures, littératures et sociétés CRIMIC-Centre de Recherches 
Interdisciplinaires sur les Mondes Ibériques Contemporains (XIXème-XXIème). Université Paris-Sorbonne, 2011.

TELLO, Mariana. "Yo acuso: un análisis antropológico sobre lo jurídicoen los primeros testimonios acerca de La Perla". In: Clepsidra. Revista interdisciplinaria de estudios sobre memoria,n4, pp.90-115, Buenos Aires, octubre de 2015.

TOLENTINO, Marcos. "Ex Detenidos Desaparecidos, Militantes pelos Direitos Humanos. As modalidades de participação dos sobreviventes dos centros clandestinos de detenção no movimento argentino pelos direitos humanos". In: SURES, volume 1, número 12, pp. 31-45, 2019.

VALDEZ, Patricia. “"Tiempo Óptimo para la memoria”. In: GROPPO, B.; FLIER, P. (comps.). La imposibilidad del olvido. Recorridos de la memoria en Argentina, Chile y Uruguay. Ed. Al Margen, La Plata, 2001.

. "El Parque de la Memoria en Buenos Aires". In: JELIN, Elizabeth; LANGLAND, Victoria (comps.). Monumentos, memoriales y marcas territoriales. Buenos Aires, Siglo XXI Editores, 2003.VECCHIOLI, 2001.

VECCHIOLI, Virginia. "Políticas de la memoria y formas de clasificación social. ¿Quiénes son las 'víctimas del terrorismo de Estado' en la Argentina?" In: GROPPO, Bruno; FLIER, P. (comps.). La Imposibilidad del Olvido. Recorridos de la Memoria en Argentina, Chile y Uruguay. La Plata: Ed. Al Margen, 2001.

“"La nación como familia'. Metáforas políticas en el movimiento argentino por los derechos humanos". In: FREDERIC, Sabrina; SOPRANO, Germán (comp.). Cultura y Politica en Etnografías sobre la Argentina. Buenos Aires: Univ. Nacional de Quilmes, 2005.

. "Repertorios militantes y expertise jurídica en la defensa de la causa de los Derechos Huamnos en la Argentina: el caso de la Liga Argentina por los Derechos del Hombre". In: Revista Ensemble. Paris, año 04, nº 9, 2012.

."Las víctimas del Terrorismo de Estado y la gestión del pasado reciente en la Argentina". In: Papeles del CEIC \#90, pp. 01-30, marzo 2013. Disponível em: http://www.ehu.eus/ojs/index.php/papelesCEIC/article/viewFile/12393/11315 Acesso em: 15 jul. 2019.

"Uma história social da expertise em direitos humanos: trajetórias transnacionais dos profissionais do Direito na Argentina". In: Estudos Ibero-Americanos, Porto Alegre, v. 45, n. 1, pp.17-28, jan.-abr. 2019.

VEIGA, Raúl. Las organizaciones de derechos humanos. Buenos Aires: Centro Editor de América Latina, 1985.

VEZZETTI, Hugo. Pasado y presente. Guerra, dictadura y sociedad en la Argentina. Buenos Aires: Siglo XXI Eds., 2009 [2002]. 
YANKELEVICH, Pablo. Ráfagas de un exilio. Argentinos en México, 1974-1983. Buenos Aires: Fondo de Cultura Económica, 2010. 